\title{
Concurrent temporal patterns in light absorbance and fish abundance
}

\author{
Tom A. Sørnes*, Dag L. Aksnes \\ Department of Biology, University of Bergen, PO Box 7800, 5020 Bergen, Norway
}

\begin{abstract}
The abundance of midwater fishes in fjord basins, as well as the abundance and size of mesozooplankton, have previously been related to optical properties of the basin water. Herein, we report on concurrent temporal changes in light absorbance and fish abundance for Masfjorden and modest changes in both variables for Lurefjorden and Sognefjorden, western Norway. The inverse relationship between fish abundance and absorbance in the temporal data, spanning $9 \mathrm{yr}$, is consistent with the relationship previously described for spatial data representing different fjords. The combination of salinity and oxygen accounted for $94 \%$ of the observed variance in absorbance of the 3 fjords, and we suggest that these variables serve as proxies for regional and local determinants of absorbance in fjord basins, respectively. While salinity indicates basin water origin and its optical properties, oxygen is a measure of turnover time and local degradation of organic matter, presumably affecting absorbance.
\end{abstract}

KEY WORDS: Light absorbance $\cdot$ Fish abundance $\cdot$ Fjords

\section{INTRODUCTION}

The mesopelagic fishes Benthosema glaciale and Maurolicus muelleri are dominant planktivores in deep, western Norwegian fjords (Kristoffersen 1999, Salvanes 2001, Aksnes et al. 2004). The fjord basins, extending from sill depth down to the bottom, make up the main part of their habitat (Salvanes 2001, 2005). The 2 species have been intensively studied in Masfjorden, western Norway (reviewed by Salvanes 2001), where they position themselves vertically according to the ambient light level (Baliño \& Aksnes 1993) and conduct extensive diel migrations (Kaartvedt et al. 1996, 1998), suggesting that light is an important cue for their life history decisions. This observed sensitivity to water column optics initiated studies on the optical properties of the basin water in Lurefjorden and Masfjorden, 2 contrasting pelagic ecosystems (Eiane et al. 1999). The deep basin of Lurefjorden is almost devoid of fishes (Eiane et al. 1999, Aksnes et al. 2004), but experiences persistent mass occurrences of the coronate scyphomedusa Periphylla periphylla (Youngbluth \& Båmstedt 2001 and references therein).
Because the light absorbance coefficient in Lurefjorden was $~ 3$ times higher than in Masfjorden, Eiane et al. (1999) suggested that the light levels of Masfjorden's basin water were several orders of magnitude higher than in Lurefjorden. This led to the question 'Fish or jellies - a question of visibility?', which was further investigated by Aksnes et al. (2004). An intensive survey of 12 western Norwegian fjords revealed that the abundance of mesopelagic fishes was inversely proportional to absorbance, suggesting that the fishes were light-limited in the fjord basins (Aksnes et al. 2004). Hence, fjords with elevated absorbance tend to have reduced stocks of mesopelagic fishes, which in turn seems to affect the abundance and size distribution of mesozooplankton (Bagøien et al. 2001, Aksnes et al. 2004).

Although the correlation between fish abundance and light absorbance was strong, the temporal resolution of the field investigations by Aksnes et al. (2004) was restricted $(<1 \mathrm{yr})$. Relationships between fish abundance and absorbance on a temporal, as well as on a spatial scale would support the impression of water column optics directly influencing the carrying 
capacity of fishes. Herein, we report on temporal patterns (1996 to 2004) of absorbance and the abundance of mesopelagic fishes for Lurefjorden, Masfjorden and Sognefjorden, western Norway. The 2 variables were relatively persistent for Lurefjorden and Sognefjorden, while Masfjorden experienced substantial changes in both. Possible causes for such changes are analysed and discussed with reference to water mass origin and basin water residence time.

\section{MATERIALS AND METHODS}

Lurefjorden, Masfjorden and Sognefjorden are located on the Norwegian west coast (Fig. 1); their topographical characteristics are listed in Table 1. Data on light absorbance of basin water and the abundance of mesopelagic fishes are presented from cruises conducted in winter (October to January) 1996, 1999, 2000 and 2004 (Table 2). Winter sampling has the advantages of (1) no primary production, making the absorbance estimates more conservative and representative of the harsh non-productive period, (2) short daylength, restricting the time window for visual feeding, and (3) avoiding the recruitment season of the studied species (Salvanes 2001, 2005). All the cruises were performed with the research vessel RV 'Håkon Mosby', and the sampling protocol (see below) was identical on all cruises. Some of the data from 1996 to 2000 have been included in previous publications (Eiane et al. 1999, Bagøien et al. 2001, Aksnes et al. 2004); however, those studies focused on structural differences between fjords and did not address temporal changes or persistence within fjords.

Triplicate measurements of salinity, temperature and dissolved oxygen were obtained using a Seabird SBE 911 CTD (Sea-Bird Electronics). Duplicate water samples were collected every $50 \mathrm{~m}$ between 100 and $300 \mathrm{~m}$ depth with 121 rosette-mounted Niskin water collectors. The samples were analysed for light absorbance using a spectrophotometer (UV/VIS Spectrometer Lambda 2, Perkin Elmer). Duplicate readings were performed at 400,420, 450, 500 and $550 \mathrm{~nm}$ wavelength for each sample. Because of observed anomalies in the salinity profiles (see 'Results'), additional water samples were analysed from 300 to $450 \mathrm{~m}$ in Masfjorden in November 2004 (Table 3).

The abundance (total area of backscattering, $S_{A}$ ) of mesopelagic fishes was assessed acoustically with a SIMRAD EK500 $38 \mathrm{kHz}$ echosounder and the Bergen Echo Integrator (BEI) system. To exclude zooplankton and larger piscivores from the estimates,

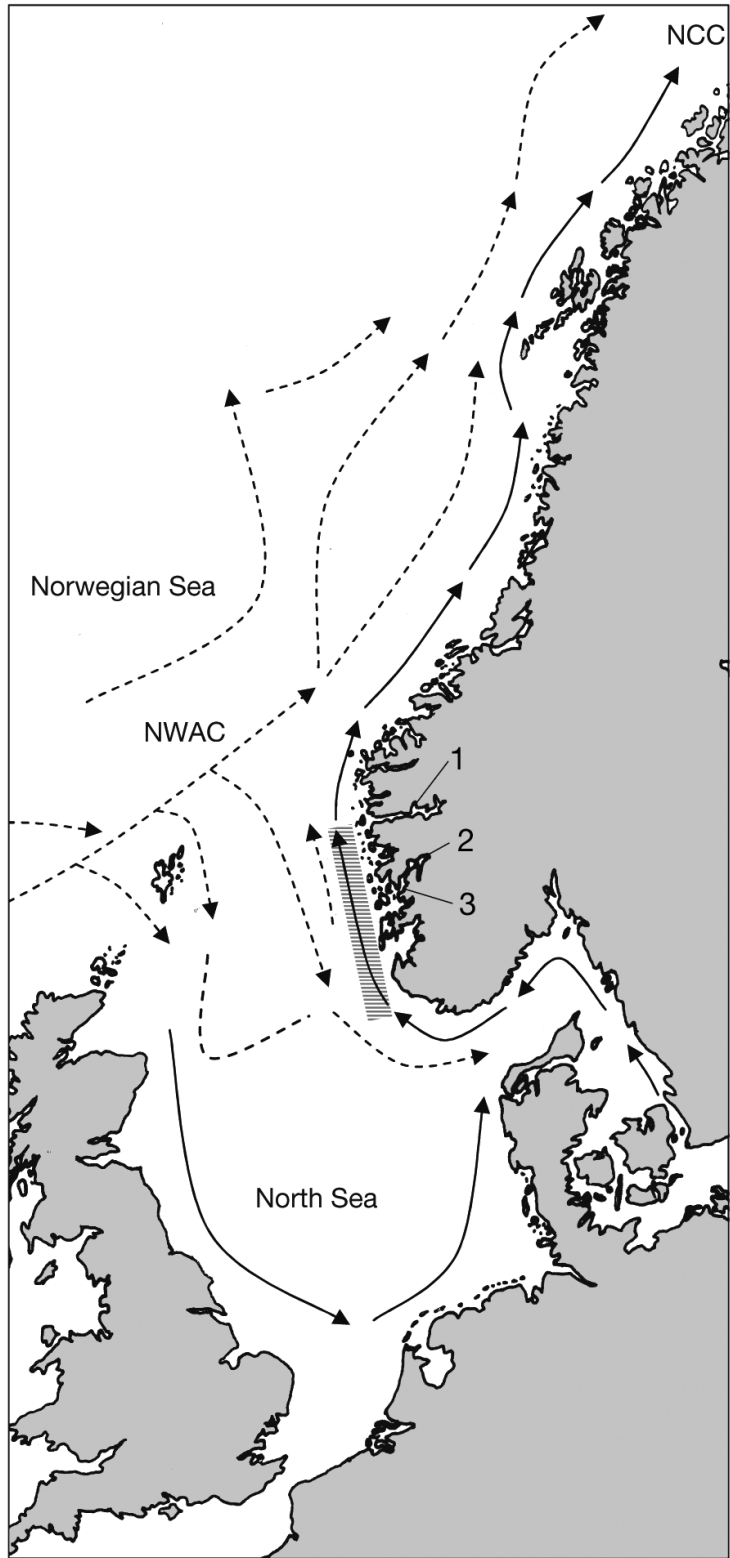

Fig. 1. The 3 study areas, Sognefjorden (1), Masfjorden (2) and Lurefjorden (3) on the Norwegian coast. Arrows indicate main paths of dominant currents; see 'Discussion' for further details. The Norwegian Atlantic Current (NWAC) and Norwegian Coastal Current (NCC) transport North Atlantic water and Norwegian coastal water, respectively. Hatched area outlines western part of Norwegian Trench, wherein Norwegian trenchwater lies. (Based on Hansen \& Østerhus 2000)

Table 1. Topographical characteristics of Lurefjorden, Masfjorden and Sognefjorden, western Norway

\begin{tabular}{|lccccc|}
\hline Fjord & $\begin{array}{c}\text { Length } \\
(\mathrm{km})\end{array}$ & $\begin{array}{c}\text { Bottom depth } \\
(\mathrm{m})\end{array}$ & $\begin{array}{c}\text { Sill depth } \\
(\mathrm{m})\end{array}$ & $\begin{array}{c}\text { Surface area } \\
\left(\mathrm{m}^{2}\right)\end{array}$ & $\begin{array}{c}\text { Vol } \\
\left(\mathrm{m}^{3}\right)\end{array}$ \\
\hline Lurefjorden & 22 & 439 & 20 & $39.2 \times 10^{6}$ & $5.7 \times 10^{9}$ \\
Masfjorden & 20 & 494 & 75 & $26.2 \times 10^{6}$ & $5.4 \times 10^{9}$ \\
Sognefjorden & 178 & 1304 & 165 & $95.0 \times 10^{7}$ & $5.3 \times 10^{11}$ \\
\hline
\end{tabular}


values above the $-65 \mathrm{~dB}$ and below the $-85 \mathrm{~dB}$ volume backscattering thresholds were omitted (Bagøien et al. 2001). The acoustic estimates primarily reflected Benthosema glaciale and Maurolicus muelleri. The transects were 3 to $5 \mathrm{~km}$ long and the $S_{A}$ values calculated for each square nautical mile (n mile ${ }^{-2}$ ) were subsequently averaged per cruise and fjord.

Table 2. Mean $( \pm$ SE) light absorbance (averaged for 100 to $300 \mathrm{~m}$ depth and 400 to $550 \mathrm{~nm}$ wavelength) and acoustical estimates of fish abundance, $S_{A}$ (= total area of backscattering) for Lurefjorden, Masfjorden and Sognefjorden, western Norway

\begin{tabular}{|lcc|}
\hline Year & Absorbance $\left(\mathrm{m}^{-1}\right)$ & $S_{A}\left(\mathrm{~m}^{2}\right.$ nautical mile $\left.{ }^{-2}\right)$ \\
\hline $\begin{array}{c}\text { Lurefjorden } \\
1996\end{array}$ & $0.061 \pm 0.000$ & 0 \\
1999 & $0.091 \pm 0.001$ & $14 \pm 4$ \\
2000 & $0.091 \pm 0.001$ & $11 \pm 6$ \\
2004 & $0.077 \pm 0.001$ & $49 \pm 10$ \\
Masfjorden & & \\
1996 & $0.020 \pm 0.000$ & $1435 \pm 182$ \\
1999 & $0.071 \pm 0.000$ & $181 \pm 30$ \\
2000 & $0.065 \pm 0.001$ & $120 \pm 30$ \\
2004 & $0.032 \pm 0.002$ & $883 \pm 128$ \\
Sognefjorden & & \\
1996 & $0.025 \pm 0.001$ & $496 \pm 11$ \\
2000 & $0.038 \pm 0.003$ & $407 \pm 3$ \\
2004 & $0.020 \pm 0.003$ & $715 \pm 43$ \\
\hline
\end{tabular}

Table 3. Depth-specific values (mean $\pm \mathrm{SE}$ ) of salinity, oxygen concentration and light absorbance (averaged for 400 to $550 \mathrm{~nm}$ wavelength) in 2004 for Lurefjorden, Masfjorden and Sognefjorden, western Norway

\begin{tabular}{|c|c|c|c|}
\hline $\begin{array}{l}\text { Depth } \\
\text { (m) }\end{array}$ & Salinity & $\begin{array}{c}\text { Oxygen } \\
\left(\mathrm{ml} \mathrm{l}^{-1}\right)\end{array}$ & $\begin{array}{c}\text { Absorbance } \\
\left(\mathrm{m}^{-1}\right)\end{array}$ \\
\hline \multicolumn{4}{|c|}{ Lurefjorden } \\
\hline 100 & $32.977 \pm 0.002$ & $4.598 \pm 0.025$ & $0.066 \pm 0.000$ \\
\hline 150 & $33.092 \pm 0.000$ & $3.669 \pm 0.010$ & $0.064 \pm 0.003$ \\
\hline 200 & $33.111 \pm 0.000$ & $3.380 \pm 0.001$ & $0.076 \pm 0.000$ \\
\hline 250 & $33.106 \pm 0.003$ & $3.132 \pm 0.019$ & $0.087 \pm 0.002$ \\
\hline 300 & $33.102 \pm 0.000$ & $2.870 \pm 0.005$ & $0.093 \pm 0.005$ \\
\hline \multicolumn{4}{|c|}{ Masfjorden } \\
\hline 100 & $34.834 \pm 0.001$ & $5.036 \pm 0.010$ & $0.029 \pm 0.001$ \\
\hline 150 & $34.950 \pm 0.001$ & $4.665 \pm 0.001$ & $0.036 \pm 0.009$ \\
\hline 200 & $34.965 \pm 0.000$ & $4.855 \pm 0.002$ & $0.033 \pm 0.002$ \\
\hline 250 & $34.979 \pm 0.000$ & $5.076 \pm 0.000$ & $0.025 \pm 0.003$ \\
\hline 300 & $34.977 \pm 0.000$ & $4.278 \pm 0.013$ & $0.036 \pm 0.003$ \\
\hline 350 & $34.976 \pm 0.000$ & $2.701 \pm 0.006$ & $0.038 \pm 0.001$ \\
\hline 400 & $34.976 \pm 0.000$ & $2.573 \pm 0.002$ & $0.055 \pm 0.001$ \\
\hline 450 & $34.976 \pm 0.000$ & $2.505 \pm 0.008$ & $0.059 \pm 0.003$ \\
\hline \multicolumn{4}{|c|}{ Sognefjorden } \\
\hline 100 & $34.990 \pm 0.002$ & $5.871 \pm 0.039$ & $0.012 \pm 0.005$ \\
\hline 150 & $35.000 \pm 0.000$ & $5.853 \pm 0.031$ & $0.017 \pm 0.003$ \\
\hline 200 & $35.016 \pm 0.001$ & $6.018 \pm 0.031$ & $0.015 \pm 0.004$ \\
\hline 250 & $35.024 \pm 0.001$ & $6.039 \pm 0.024$ & $0.019 \pm 0.004$ \\
\hline 300 & $35.024 \pm 0.000$ & $5.973 \pm 0.021$ & $0.020 \pm 0.006$ \\
\hline
\end{tabular}

\section{RESULTS}

\section{Basin water}

The basin water in Lurefjorden was, by definition, Norwegian coastal water (NCW, salinity <34.50) during the entire study period (Fig. 2a). The $20 \mathrm{~m}$ deep sill prevents the intrusion of the denser Norwegian trenchwater (NTW, salinity 34.50 to 34.95 ) and Atlantic water (AW, salinity > 34.95). In Masfjorden, a pronounced layer of NCW and NTW extended down to $\sim 220 \mathrm{~m}$ in January 2000. This anomaly was not observed in 1996, 1999 or 2004 (Fig. 2b,d), when AW dominated. The deep basin of Sognefjorden contained AW on all cruises (Fig. 2c).

\section{Light absorbance}

Lurefjorden basin water had the highest light absorbance $\left(0.061\right.$ to $\left.0.091 \mathrm{~m}^{-1}\right)$ during the entire study period, and Sognefjorden the lowest $(0.020$ to $0.038 \mathrm{~m}^{-1}$, Table 2). The estimates of absorbance in Masfjorden were comparable to those in Sognefjorden in 1996 and $2004(0.020 \pm 0.000$ [SE] and $0.032 \pm$ $0.002 \mathrm{~m}^{-1}$, respectively), but approached the elevated levels of Lurefjorden in 1999 and 2000 (0.071 \pm 0.000 and $0.065 \pm 0.001 \mathrm{~m}^{-1}$, respectively).

\section{Abundance of mesopelagic fishes}

The acoustic estimates of fish abundance (Table 2) were consistently low and high for Lurefjorden $\left(S_{A}<49 \pm 10[\mathrm{SE}]\right)$ and Sognefjorden $\left(S_{A}>407 \pm 3\right)$, respectively. In Masfjorden, the estimates were 1 order of magnitude lower in 1999 and $2000\left(S_{A}=181 \pm\right.$ 30 and $120 \pm 30$, respectively) than in $1996\left(S_{A}=1435\right.$ $\pm 182)$, but increased again in $2004\left(S_{A}=883 \pm 128\right)$. The abundances of mesopelagic fishes were inversely proportional to light absorbance (Fig. 3).

\section{Light absorbance versus salinity and dissolved oxygen}

Complete profiles of dissolved oxygen, from surface to bottom, were only obtained in 2004, and the subsequent analyses exclusively involved the 2004 data set. Considering the 3 fjords together, $94 \%$ of the variation in light absorbance was explained by the combination of salinity and dissolved oxygen (multiple regression, $\mathrm{r}^{2}=0.94, \mathrm{df}=$ $2,15, \mathrm{p}<10^{-4}$ ) (Table 3). Both regression coefficients ( $\beta$-salinity and $\beta$-oxygen) were statistically significant $(p<0.05)$. The regression between salinity and dissolved oxygen was not significant $\left(r^{2}=0.13, p>0.05, n=18\right)$. 

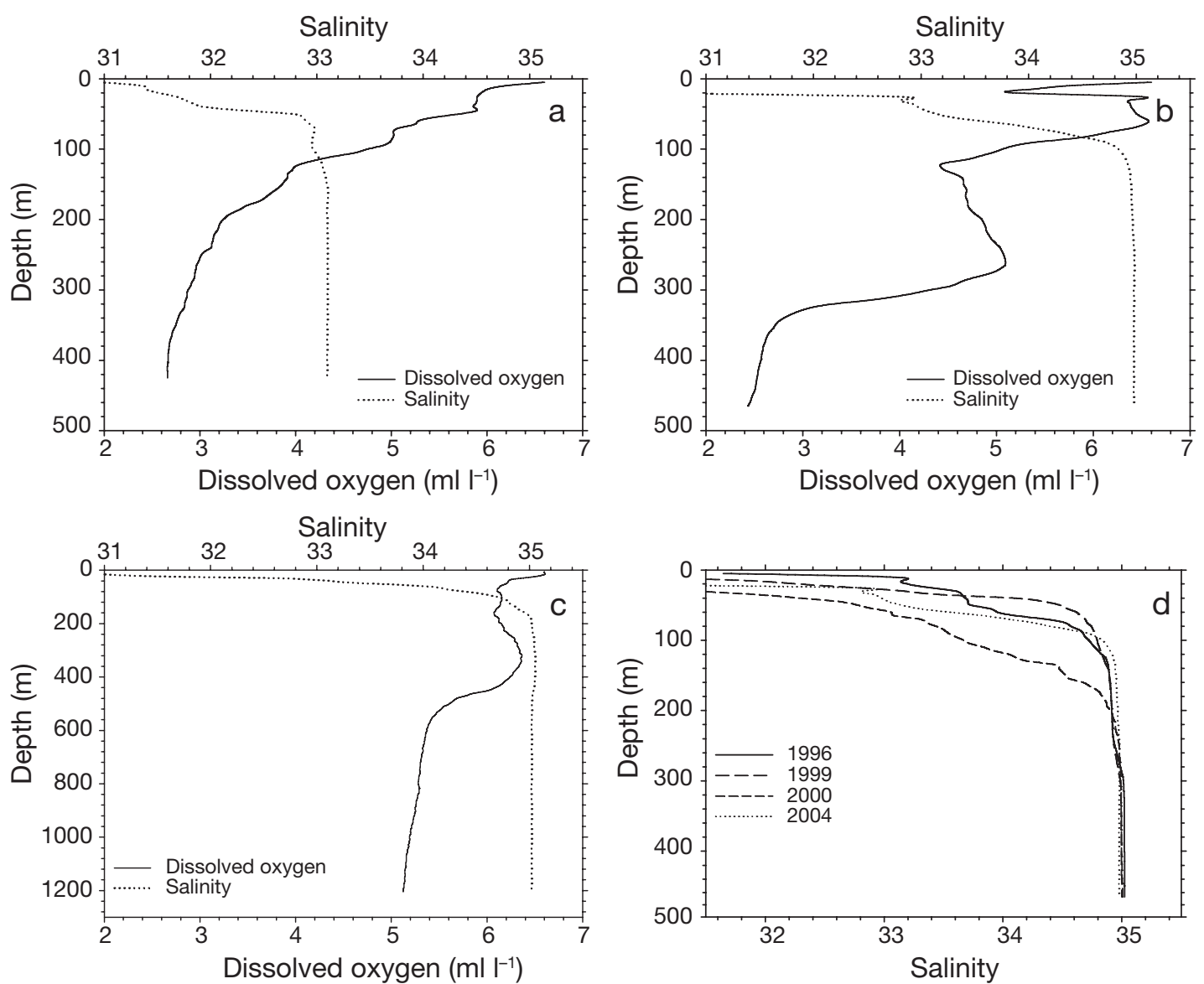

Fig. 2. Representative profiles of salinity and dissolved oxygen in (a) Lurefjorden, (b) Masfjorden and (c) Sognefjorden, western Norway. (d) Because of interannual variations (see 'Results'), salinity profiles for all 4 yr (1996, 1999, 2000 and 2004 ) are shown for Masfjorden. See 'Results' and 'Discussion' for further details

\section{DISCUSSION}

Aksnes et al. (2004) demonstrated that the abundance of mesopelagic fishes was inversely proportional to light absorbance of basin water, when comparing 12 fjords over a restricted time period $(<1 \mathrm{yr})$. The coherence between fish abundance and absorbance suggested light-limitation in the visual foraging process. Our temporal data (1996 to 2004) suggest that the low and high abundances of mesopelagic fishes in Lurefjorden and Sognefjorden, respectively, reflected persistently high and low levels of absorbance (Fig. 3, Table 2). In contrast, the absorbance of Masfjorden changed substantially ( 3-fold) during the study period, with concurrent changes in the abundance of mesopelagic fishes (Fig. 3, Table 2). In Masfjorden, the alterations in fish abundance as a function of absorbance are consistent with the relationship previously obtained between fjords (Aksnes et al. 2004). Although the time-series only contains data from 4 different years, the regression between fish abundance and the inverse of the absorbance is highly significant $\left(S_{A}=\right.$ $\left.37 a^{-1}-366, p=0.008, n=4\right)$. The temporal observations therefore support the hypothesis of light-limited visual feeding in fjord basins.

It is uncertain whether the changes in the abundance of mesopelagic fishes in Masfjorden reflect changes in local growth processes or an exchange with connected fjords and coastal areas. A less favourable habitat may have resulted in horizontal migration from Masfjorden and vice versa. However, genetic divergence has been revealed between fjord and offshore populations (Suneetha \& Næevdal 2001, Suneetha \& Salvanes 2001), and the small size of these fishes make horizontal migrations disadvantageous (Nøttestad et al. 1999). The fjord populations are therefore considered semi-enclosed entities, suggesting that population regulations take place on a local scale.

Eiane et al. (1999) found a negative relation between light absorbance and salinity and attributed the elevated levels of absorbance in Lurefjorden to the high proportion of NCW. NCW originates from the Baltic and North Sea and flows northwards along the Norwegian coast (Fig. 1). In the Baltic and North Sea regions, 


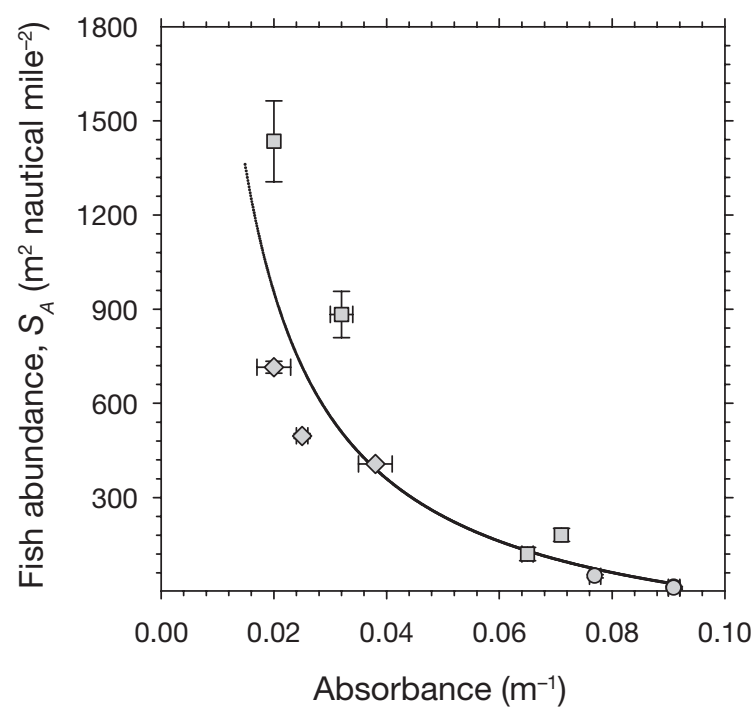

Fig. 3. Mean $( \pm \mathrm{SE})$ abundance of mesopelagic fishes versus light absorbance of basin water (averaged for 100 to $300 \mathrm{~m}$ depth and 400 to $550 \mathrm{~nm}$ wavelength) during 1996 to 2004 (see Table 2) in Lurefjorden (O), Masfjorden ( $\square$ ) and Sognefjorden $(\diamond)$. Fitted curve $\left(S_{A}=24 a^{-1}-241, \mathrm{r}^{2}=0.77\right)$ is reproduced from Aksnes et al. (2004)

substantial amounts of dissolved organic matter ('yellow substance') are transported to coastal waters by rivers and rainfall (Aure \& Skjoldal 2003). Subsurface light is absorbed by water, suspended particles and dissolved organic matter. Pure water is a weak absorber of blue and green wavelengths (450 to $550 \mathrm{~nm}$ ), while absorption generally increases for particulate organic and dissolved compounds (yellow substance) as wavelength decreases into the blue and ultraviolet (<550 nm, Kirk 1994). Yellow substance is considered a quasi-conservative parameter, because it decomposes slowly and does not precipitate in waters with salinities $>6$ (Højerslev et al. 1996). Several studies have found a negative relation between yellow substance and salinity, and have used these relationships for water mass identification (Højerslev et al. 1996 and references therein). Baltic sea water is characterised by low salinities and an intermediate to high content of yellow substance. AW, principally unaffected by coastal run-off, contains less yellow substance. Since the deep basin in Lurefjorden was filled with NCW, while AW predominated in Sognefjorden, the persistently high and low absorbances in Lurefjorden and Sognefjorden, respectively, were not surprising. The conditions were more complex in Masfjorden, where the sill depth $(75 \mathrm{~m})$ is intermediate to that of Lurefjorden $(20 \mathrm{~m})$ and Sognefjorden $(165 \mathrm{~m})$. The composition of the basin water in Masfjorden changed over the years, with different proportions of NCW, NTW and AW (Fig. 2b,d).

Based on the regression between light absorbance (a) and salinity ( $s$ ) presented in Eiane et al. (1999), $a=$
$-0.036 s+1.308\left(r^{2}=0.94\right)$, a decrease in salinity from 35 to 33 leads to an increase in absorbance from 0.048 to $0.120 \mathrm{~m}^{-1}$. When integrated over hundreds of metres, such differences have severe consequences for the levels of ambient illumination. Our data covered a much narrower salinity range, and the regression between absorbance and salinity $\left(\mathrm{r}^{2}=0.73, \mathrm{p}<10^{-4}\right.$, $\mathrm{n}=18$ ) explained $21 \%$ less of the observed variance than the regression analysis of Eiane et al. (1999). However, an additional $21 \%$ of the variance could be attributable to oxygen (multiple regression, $\mathrm{r}^{2}=0.94$, $\mathrm{p}<10^{-4}, \mathrm{n}=18$ ). The concentration of oxygen in the basin water is negatively influenced by the input of organic material and the exchange rate of the basin water, the latter depending on basin and sill depth (Aure \& Stigebrandt 1989). Our data suggest that, for a given fjord basin, absorbance increases when the oxygen content decreases (Fig. 4, Table 3). While basin water salinity primarily reflects the origin of the water on a regional scale, the oxygen content also reflects processes influencing absorbance on a more local scale. The decomposition of organic material in the basin water probably causes elevated concentrations of compounds that enhance absorbance.

Field investigations cannot offer the same degree of control as experimental studies, and it is inherently difficult to distinguish causality from correlation. In our data, light absorbance related well to the combination of salinity and oxygen. Could the relationship between fish abundance and absorbance merely be a correlation and salinity or oxygen the 'real' explanatory variables? Although this cannot be entirely excluded, there are several counter-arguments. First, the ob-

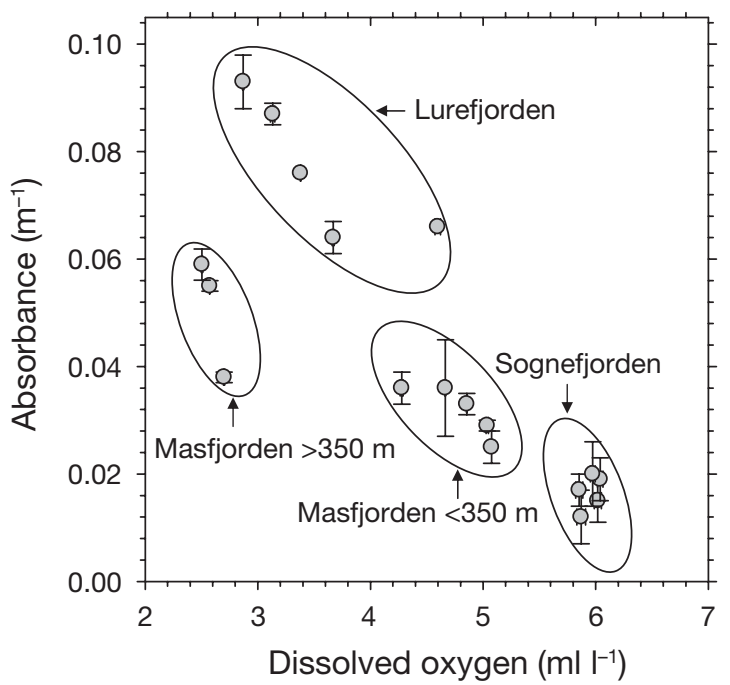

Fig. 4. Mean $( \pm \mathrm{SE})$ light absorbance (averaged for 100 to $300 \mathrm{~m}$ depth and 400 to $550 \mathrm{~nm}$ wavelength) versus dissolved oxygen of basin water in Lurefjorden, Masfjorden and Sognefjorden, western Norway, November 2004 
served salinity range (33 to 35 ) is small and poses no physiological challenges to fishes (Schmidt-Nielsen 1997). Second, the concentrations of oxygen in the fjords were well above what is normally defined as hypoxia (present Fig. 2, and Diaz \& Rosenberg 1995). The low concentrations recorded below $300 \mathrm{~m}$ in Masfjorden, November 2004 (Table 3), were surprising, since previous measurements have been consistently above $4 \mathrm{ml} \mathrm{l}^{-1}$ (Aksnes et al. 1989, Bagøien 1999). However, the lower content of oxygen did not seem to adversely affect the abundance of mesopelagic fishes, which was high at that time (Table 2). On the other hand, the absorbance was substantially lower in 1996 and $2004\left(0.020\right.$ to $\left.0.032 \mathrm{~m}^{-1}\right)$ than in 1999 and 2000 (0.065 to $\left.0.071 \mathrm{~m}^{-1}\right)$. In a $300 \mathrm{~m}$ water column, an increase in absorbance of about $0.04 \mathrm{~m}^{-1}$ reduces the ambient illumination by 5 orders of magnitude. It seems plausible that such an alteration can severely influence the habitat profitability and production of mesopelagic fishes, with consequences for other trophic levels.

We conclude that the concurrent temporal patterns in light absorbance and abundance of mesopelagic fishes for the 3 fjords are consistent with visually constrained foraging. However, more observations are needed to evaluate the generality of this relationship for fjord basins and to further identify the factors causing the changes in absorbance. In addition to the correlation between absorbance and salinity (Højerslev et al. 1996, Eiane et al. 1999), we believe that the correlation between absorbance and dissolved oxygen deserves future attention.

Acknowledgements. We are grateful to J. Aure for valuable comments on the manuscript, E. Bagøien for assistance in retrieving data from earlier cruises and T. Torgersen for providing shiptime in November 2004. Financial support was provided by the European Union Fisheries Directorate, through Contract QLRS-2002-00799, Project ETHOFISH.

\section{LITERATURE CITED}

Aksnes DL, Aure J, Kaartvedt S, Magnesen T, Richard J (1989) Significance of advection for the carrying capacities of fjord populations. Mar Ecol Prog Ser 50:263-274

Aksnes DL, Nejstgaard JC, Sædberg E, Sørnes T (2004) Optical control of fish and zooplankton populations. Limnol Oceanogr 49:233-238

Aure J, Skjoldal HR (2003) OSPAR Common procedure for identification of eutrophication status: application of the screening procedure for the Norwegian coast north of

Editorial responsibility: Otto Kinne (Editor-in-Chief), Oldendorf/Luhe, Germany $62^{\circ} \mathrm{N}$ (Stad-Russian border). Project report, Norwegian Pollution Control Authority, Oslo

Aure J, Stigebrandt A (1989) On the influence of topographic factors upon the oxygen-consumption rate in sill basins of fjords. Estuar Coast Shelf Sci 28:59-69

Bagøien E (1999) Predatory impact of invertebrates and fish on overwintering Calanus. PhD thesis, University of Oslo, Oslo

Bagøien E, Kaartvedt S, Aksnes DL, Eiane K (2001) Vertical distribution and mortality of overwintering Calanus. Limnol Oceanogr 46:1494-1510

Baliño BM, Aksnes DL (1993) Winter distribution and migration of the sound-scattering layers, zooplankton and micronekton in Masfjorden, western Norway. Mar Ecol Prog Ser 102:35-50

Diaz RJ, Rosenberg R (1995) Marine benthic hypoxia: a review of its ecological effects and the behavioural responses of benthic macrofauna. Oceanogr Mar Biol 33: 245-303

Eiane K, Aksnes DL, Bagøien E, Kaartvedt S (1999) Fish or jellies - a question of visibility? Limnol Oceanogr 44: $1352-1357$

Hansen B, Østerhus S (2000) North Atlantic-Nordic seas exchanges. Prog Oceanogr 45:109-208

Højerslev NK, Holt N, Aarup T (1996) Optical measurements in the North Sea-Baltic Sea transition zone. 1. On the origin of the deep water in the Kattegat. Cont Shelf Res 16: 1329-1342

Kaartvedt S, Melle W, Knutsen T, Skjoldal HR (1996) Vertical distribution of fish and krill beneath water of varying optical properties. Mar Ecol Prog Ser 136:51-58

Kaartvedt S, Knutsen T, Holst JC (1998) Schooling of the vertically migrating mesopelagic fish Maurolicus muelleri in light summer nights. Mar Ecol Prog Ser 170:287-290

Kirk JTO (1994) Light and photosynthesis in aquatic ecosystems. Cambridge University Press, Cambridge

Kristoffersen JB (1999) Mesopelagic fish in Norwegian waters: distribution, life history and genetics. PhD thesis, University of Bergen, Bergen

Nøttestad L, Giske J, Holst JC, Huse G (1999) A length-based hypothesis for feeding migrations in pelagic fish. Can $\mathrm{J}$ Fish Aquat Sci 56:26-34

Salvanes AGV (2001) Review of ecosystem models of fjords; new insights of relevance to fisheries management. Sarsia 86:441-463

Salvanes AGV (2005) Mesopelagic fish. In Skjoldal HR (ed) The Norwegian sea ecosystem. Tapir Academic Press, Trondheim, p 301-314

Schmidt-Nielsen K (1997) Animal physiology, 5th edn. Cambridge University Press, New York

Suneetha KB, Nævdal G (2001) Genetic and morphological stock structure of the pearlside, Maurolicus muelleri (Pisces, Sternoptychidae), among Norwegian fjords and offshore area. Sarsia 86:191-201

Suneetha KB, Salvanes AGV (2001) Population genetic structure of the glacier lanternfish, Benthosema glaciale (Myctophidae), in Norwegian waters. Sarsia 86:203-212

Youngbluth MJ, Båmstedt U (2001) Distribution, abundance, behavior, and metabolism of Periphylla periphylla, a mesopelagic coronate medusa in a Norwegian fjord. Hydrobiologia 451:321-333

Submitted: September 16, 2005; Accepted: March 6, 2006 Proofs received from author(s): October 9, 2006 